\title{
Indoor climate and energy performance in nearly zero energy day care centers and school buildings
} \author{
and Jarek Kurnitski ${ }^{1,2}$ \\ ${ }^{1}$ Department of Civil Engineering, Aalto University, Finland \\ ${ }^{2}$ Department of Civil Engineering and Architecture, Tallinn University of Technology, Estonia \\ ${ }^{3}$ Kouvola Innovation Oy, Finland \\ ${ }^{4}$ Sintef Building and Infrastructure, Architecture, Materials and Structures, Norway
}

Kaiser Ahmed ${ }^{1,{ }^{*}}$, Kalle Kuusk ${ }^{2}$, Henrik Heininen ${ }^{1}$, Endrik Arumägi ${ }^{2}$, Targo Kalamees ${ }^{2}$, Tero Hasu ${ }^{3}$, Nicola Lolli ${ }^{4}$,

\begin{abstract}
This study presents the assessment of actual indoor climate condition and energy performance in eight NZEB school and daycare centers of NERO H2020 project. Physical parameters such as indoor temperature, relative humidity, $\mathrm{CO}_{2}$, airflow rate and temperature were measured during heating and cooling seasons, in parallel with an occupants' questionnaires survey. Besides, calculated and measured energy data was collected from energy performance certificates and energy bills. Thermal comfort and IAQ were assessed based on categories in EN15251 standard with color footprints. Results showed that all the buildings had good or excellent indoor climate during the heating season. However, a large percentage of occupied hours were categorized as category IV during the cooling season, which mainly occurred due to too low indoor temperature caused by the low outdoor temperature during the measurement period. Also, all buildings achieved low $\mathrm{CO}_{2}$ levels. Moreover, the conducted questionaries' survey showed good correlation with measured results for all buildings except in one building, which had odor and noise problems. In contrast, the measured energy use in 5 buildings out of 7 was increased by factor 2.1-3.0 compared to calculated annual energy use due to a full-time operation of the ventilation system and presence of hot kitchens.
\end{abstract}

Keywords: Thermal comfort; Indoor air quality; Questionaries' survey; Energy consumption

\section{Introduction}

Energy efficiency and indoor environment quality (IEQ) measures are the prominent topics in the building industry, which require to ensure a comfortable and healthy indoor environment within minimum energy use in buildings. These two concepts need to be balanced that fulfill the actual purposes of buildings. Educational buildings require more attention because of having special characters such as occupancy rate, pattern, activities, and many more. Besides, children and student spend a good percentage of daily hours in daycare and school buildings; it looks so obvious to ensure a healthy environment for them. On the other hand, energy is the second highest expenses in educational buildings that lead 6 billion dollars per year in the United States [2]. Due to the particular occupancy schedule, Cabrera et al. [3] demonstrated the lighting control strategy in an educational building that reported a good percentage of energy savings and discovered the pattern of energy wastage.

Many studies reported the IEQ assessment and energy use in buildings simultaneously [4-9]. Dascalaki et al. [9] reported the energy performance and IEQ in Hellenic school building stock. The results found that excessive energy consumption due to the absence of a control system of heating and lighting. Also, deteriorated IAQ in classrooms, glare problems, noise disturbances, and thermal discomforts were also noticed [9]. In a similar context, Ghita et al. [8] investigated the energy efficiency and IEQ in Romanian countrysides' new and renovated schools. The onsite measurements and survey report found that the $\mathrm{CO} 2$ concentrations were in 2000-3000 ppm and thermal comfort was not achieved during the winter season while the outdoor temperature of $0{ }^{\circ} \mathrm{C}$ or less. However, energy consumption rating of both buildings was 'A class' [8]. Moreover, on-site measurements of indoor temperature and IAQ, questionnaires survey were conducted in Finnish school building, aiming to assess the thermal comfort, IAQ and odor intensity $[10,11]$. The effect of ventilation intervention on measured and perceived IAQ had found noticeable improvement.

Several authors addressed the potential reasons such as uncertainties at design stage, construction errors, occupant behavior toward indoor thermal condition, weather condition, HVAC control system, and many more that kept gaps in between predicted and measured energy use $[12,13]$. De Wilde reported that the most common errors were uncertainties at design stage and construction errors [12]. Also, prediction of the user behaviors and lack of information about systems' efficiency were other potential causes, which showed the deviation of energy use from $12-44 \%[13,14]$. In a similar context, heating energy use in buildings was influenced by heating setpoint temperature, which mainly driven by the occupant behavior [15]. A small change of set point temperature could show potential impact on final energy use in buildings. Moreover, a feasible and realistic HVAC control system with detailed systems' efficiency information needs to consider in simulation tools, which can minimize the energy performance gap.

The objective of this study is to assess the indoor climate condition and energy performance of low energy daycare centers and school buildings. The onsite measurements and questionaries' survey were conducted 
during the heating and cooling seasons. The detailed building information, operational strategy, building facility, energy consumption data were also collected, which explained the indoor climate performance and the performance gap of energy use in buildings.

\section{Methods}

The detailed building information and technical systems data have discussed in Section 2.1 and 2.2. Also, onsite measurements were taken from daycare centers and school buildings during both seasons, which have explained in Section 2.3. Furthermore, a questionaries' survey about the indoor climate condition during the measurement periods have also reported.

\subsection{Building description}

This study was carried out in comprehensive two daycare centers (F1, F2) and three school buildings (F3, F4, F5) in Finland and two daycare centers (E1, E2) in Estonia. All buildings are very new buildings and have classified as 'Teaching buildings and daycare centers.' The buildings were selected in cooperation with municipalities, based on their building structure. The general views of buildings are shown in Figure 1. These buildings such as F1, F2, F3,
F4, and E1 were wooden buildings, which made from wooden frame and elements. These buildings had similar external wooden frame wall, wooden floor, and roof structure. Typical exterior wall, roof, and base floor types are shown in Figure 2. The building F5 was made from the prefabricated concrete frame (beams, columns) and partly made from elements. The external wall was made of brick followed by an air gap, thermal insulation, and board. The basement, interior floor, and roof were made of vapor barrier, air gap, blown mineral wool, and hollow concrete slab. Building E2 was built from concrete elements. The detailed thermal transmittance ( $U$ value) are shown in Table 1. There are four weather zones in Finland. Buildings F1-F2 and F3-F4 belong to Zone 1 and 2 , respectively. The annual average outdoor temperatures are 5.3 and $4.6{ }^{\circ} \mathrm{C}$ for Zone 1 and 2. In Estonia, there is 1 climate zone with average annual outdoor temperature 5.7 ${ }^{\circ} \mathrm{C}$. As these building purposes are predefine, these follow the strict operation hours. The detailed of building information such as building gross area, net floor area, energy level according to the Energy Performance Certificate (EPC), heating degree days (HDD), operation hours, et cetera are shown in Table 2.

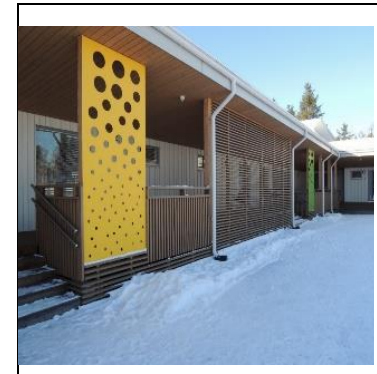

F1

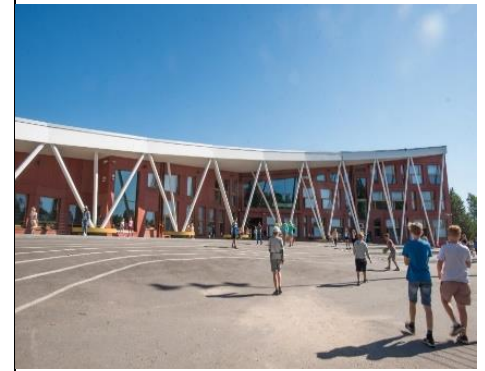

F5

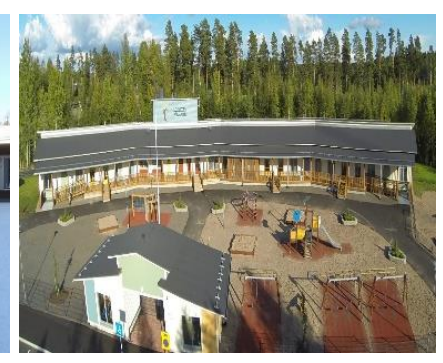

F2

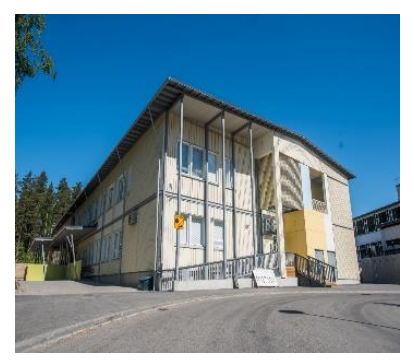

F3

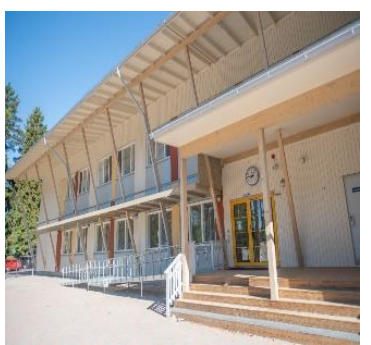

F4

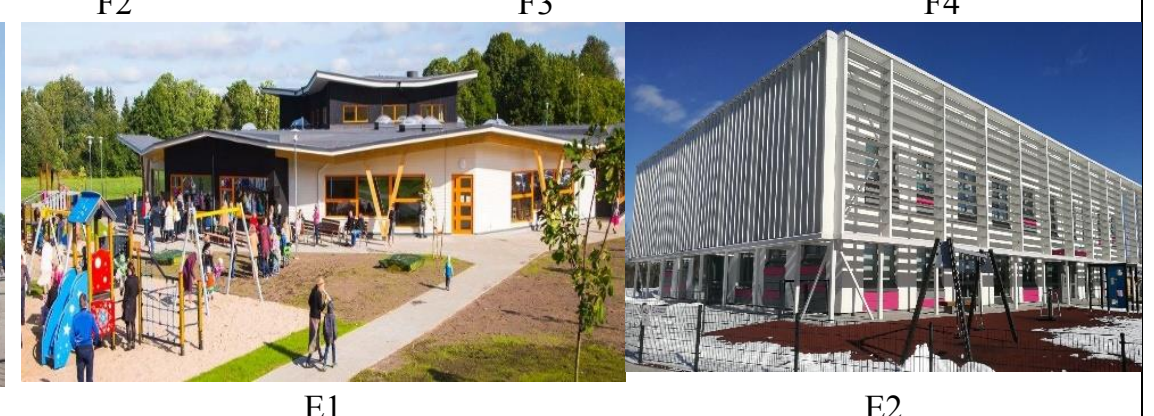

E2

Fig. 1. General views of the case studied buildings.

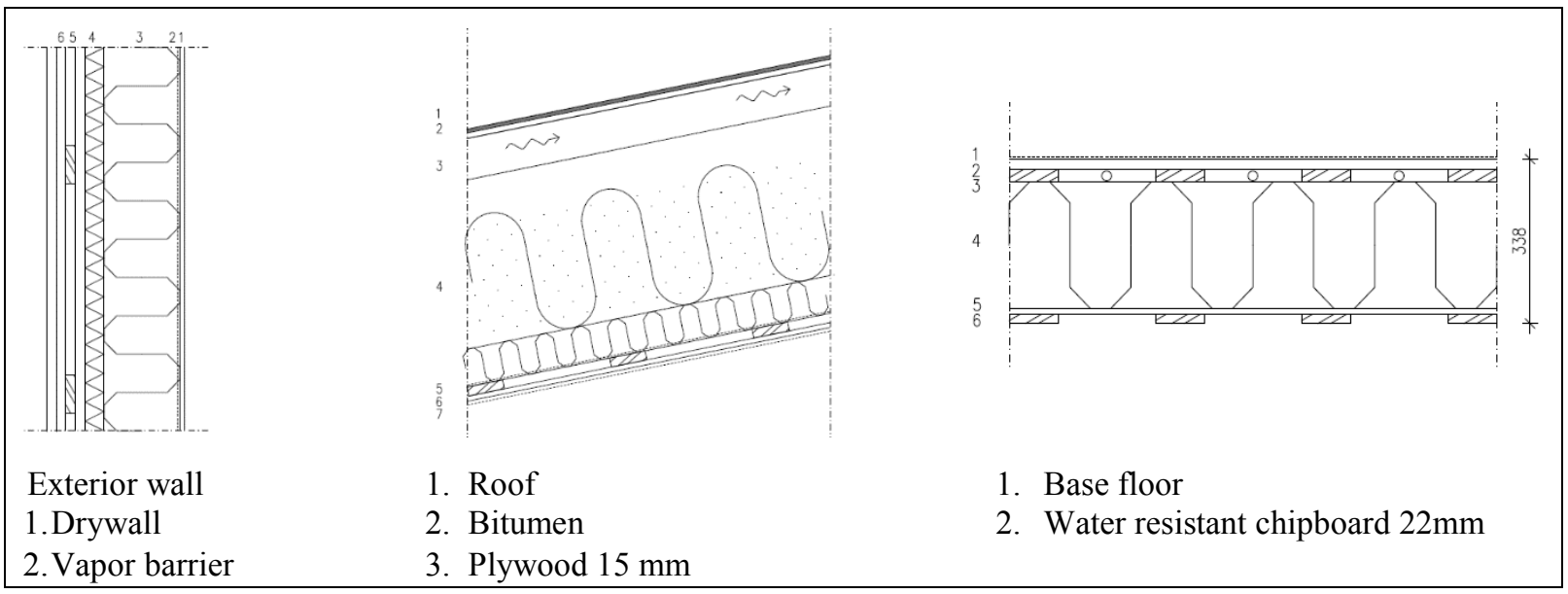




\begin{tabular}{|lll|}
\hline 3. Mineral wool $200 \mathrm{~mm}$ & 4. Support structures & 3. Heat exchange plates + floor heating \\
4. Wind barrier $50 \mathrm{~mm}$ & 5. Mineral wool $100 \mathrm{~mm}+$ blown & pipes \\
5. Air gap $25+25 \mathrm{~mm}$ & loose wool $350 \mathrm{~mm}$ & 4. Planking $25 \times 100$ \\
6. Board panel & 6. Vapor barrier & 5. Laminated veneer wood $45 \times 100+$ \\
& 7. Air gap $25 \mathrm{~mm}$ & mineral wool $260 \mathrm{~mm}$ \\
& 8. Drywall & 6. Porous wind barrier $12 \mathrm{~mm}$
\end{tabular}

Fig. 2. Typical exterior wall, roof and base floor types.

Table 1. Thermal transmittance (U-value).

\begin{tabular}{lccccccc}
\hline \multirow{2}{*}{ Building elements } & \multicolumn{3}{c}{ Finland } & \multicolumn{3}{c}{ Estonia } \\
\cline { 2 - 8 } & $\mathrm{F} 1$ & $\mathrm{~F} 2$ & $\mathrm{~F} 3$ & $\mathrm{~F} 4$ & $\mathrm{~F} 5$ & E1 & E2 \\
\hline Exterior walls, $\mathrm{W} /\left(\mathrm{m}^{2} \mathrm{~K}\right)$ & 0.17 & 0.15 & 0.17 & 0.16 & 0.10 & 0.19 & 0.13 \\
\hline Roof, $\mathrm{W} /\left(\mathrm{m}^{2} \mathrm{~K}\right)$ & 0.09 & 0.08 & 0.09 & 0.09 & 0.06 & 0.10 & 0.06 \\
\hline Ground floor, $\mathrm{W} /\left(\mathrm{m}^{2} \mathrm{~K}\right)$ & 0.16 & 0.16 & 0.16 & 0.10 & 0.12 & 0.20 & 0.09 \\
\hline Windows, $\mathrm{W} /\left(\mathrm{m}^{2} \mathrm{~K}\right)$ & 1.00 & 0.84 & 1.00 & 1.00 & 0.81 & 1.00 & 0.85 \\
\hline $\begin{array}{l}\text { Window g-value, } \\
\text { dimensionless }\end{array}$ & 0.36 & 0.36 & 0.56 & 0.56 & 0.41 & $0.25-0.50$ & 0.50 \\
\hline Doors, $\mathrm{W} /\left(\mathrm{m}^{2} \mathrm{~K}\right)$ & 1.00 & 1.00 & 1.00 & 1.00 & 0.82 & 1.00 & 1.10 \\
\hline Air tightness $\left(\mathrm{q}_{50}\right), \mathrm{m}^{3} /\left(\mathrm{h} \cdot \mathrm{m}^{2}\right)$ & 2.0 & 1.3 & 2.0 & 1.3 & 1.0 & 3.8 & 0.6 \\
\hline
\end{tabular}

Table 2. Detailed information about buildings.

\begin{tabular}{|c|c|c|c|c|c|c|c|}
\hline & \multicolumn{5}{|c|}{ Finland } & \multicolumn{2}{|c|}{ Estonia } \\
\hline & F1 & F2 & F3 & F4 & F5 & E1 & E2 \\
\hline Building type & Daycare & Daycare & $\begin{array}{c}\text { Elementary } \\
\text { school }\end{array}$ & $\begin{array}{c}\text { Elementary } \\
\text { school }\end{array}$ & $\begin{array}{l}\text { School, } \\
\text { Daycare, } \\
\text { Maternity } \\
\text { clinic }\end{array}$ & Daycare & Daycare \\
\hline Net floor area, $\mathrm{m}^{2}$ & 1170 & 1192 & 2830 & 2912 & 6908 & 1551 & 1175 \\
\hline $\begin{array}{l}\text { Gross floor area, } \\
\mathrm{m}^{2}\end{array}$ & 1262 & 1271 & 3078 & 3050 & 7395 & & \\
\hline Construction year & 2015 & 2014 & 2017 & 2017 & 2016 & 2017 & 2017 \\
\hline EPC & $\mathrm{C}$ & $\mathrm{B}$ & B & B & A & $\mathrm{C}$ & A \\
\hline $\begin{array}{l}\text { Design outdoor } \\
\text { temperature, }{ }^{\circ} \mathrm{C}\end{array}$ & -26 & -26 & -26 & -26 & -26 & -22 & -24 \\
\hline $\mathrm{HDD},{ }^{\circ} \mathrm{Cd}$ & 4392 & 4392 & 3878 & 3878 & 3878 & 4220 & 4220 \\
\hline $\begin{array}{l}\text { Operation hours, } \\
\text { hour }\end{array}$ & $\begin{array}{l}7: 00- \\
19: 00\end{array}$ & $\begin{array}{l}7: 00- \\
19: 00\end{array}$ & $\begin{array}{l}8: 00- \\
16: 00\end{array}$ & $\begin{array}{l}8: 00- \\
16: 00\end{array}$ & $8: 00-16: 00$ & $\begin{array}{l}7: 00- \\
19: 00\end{array}$ & $\begin{array}{l}7: 00- \\
19: 00\end{array}$ \\
\hline hours/year, hour & 3120 & 3120 & 2080 & 2080 & 2080 & 3120 & 3120 \\
\hline $\begin{array}{l}\text { Occupant density, } \\
\mathrm{m}^{2} / \text { per. }\end{array}$ & 10 & 10 & 7 & 7 & 7 & 10 & 12 \\
\hline
\end{tabular}

\subsection{Description of the technical system}

Buildings had different heating sources such as gas boiler, geothermal heat pump, central district heating system for space and domestic hot water (DHW) heating. The room heating provided by a floor heating system, radiators with thermostatic valve, and ceiling panels. Also, the wet room's heating in all buildings provided by the floor heating system. Moreover, the cooling system was in 4 buildings out of 7 was provided through air source heat pumps (ASHP), ground source heat pump (GSHP), and chiller. Ventilation supply air and ceiling panels were used to distribute cooling to the rooms.
All buildings had multiple air handling units (AHU), which were mainly equipped with mechanical supply and extract ventilation system with heat recovery unit. The multiple AHU units were available due to the different zone functions such as classrooms, sleeping rooms, playing rooms, corridors, kitchen, $\mathrm{WC}$, et cetera. The ventilation systems were either demand based with $\mathrm{CO}_{2}$ and temperature controlled (DCV) or constant air volume (CAV) system. The ventilation systems operated with maximum speed during building operation hours (if required) and also functioned with partial speeds during the non-occupancy hours. The details of technical systems are shown in Table 3. 


\subsection{Onsite measurement}

Onsite measurements were taken in three different rooms of each building. The rooms were selected based on the most IAQ related complaints from the occupants. Also, an overheating problem during the cooling season was in under consideration and studied at least one room from the southern part of the building. This study measured indoor temperature, $\mathrm{RH}, \mathrm{CO}_{2}$ level, supply air temperature, supply and exhaust air flow rate, pressure difference along the envelope during the heating and cooling seasons.

Temperature, $\mathrm{RH}$ were measured by ThermaData with an accuracy of $\pm 0.5^{\circ} \mathrm{C}\left(-10 \ldots 85^{\circ} \mathrm{C}\right)$. Rotronic CL100 were measured additionally the $\mathrm{CO}_{2}$ level with the accuracy of $\pm 0.3{ }^{\circ} \mathrm{C}$ of temperature, $\pm 3 \%(10 \ldots 95 \%)$ of $\mathrm{RH}, \pm 30 \mathrm{ppm}$ of $\mathrm{CO}_{2}$. The measurement were taken with 10 minutes interval during one month of heating and cooling seasons. In addition, SWEMA $3000 \mathrm{md}$ was used Table 3. Technical systems of buildings.

\begin{tabular}{|c|c|c|c|c|c|c|c|}
\hline Building code & F1 & F2 & F3 & F4 & F5 & E1 & E2 \\
\hline Heat source & $\begin{array}{l}\text { Gas } \\
\text { Boiler }\end{array}$ & GSHP & GSHP & $\begin{array}{l}\text { District } \\
\text { heating }\end{array}$ & $\begin{array}{l}\text { District } \\
\text { heating }\end{array}$ & $\begin{array}{l}\text { Gas } \\
\text { Boiler }\end{array}$ & GSHP \\
\hline Heating system & Radiator & Floor & $\begin{array}{l}\text { Ceiling } \\
\text { panel }\end{array}$ & Floor & Floor & $\begin{array}{l}\text { Floor, } \\
\text { radiator }\end{array}$ & $\begin{array}{l}\text { Floor, } \\
\text { radiator }\end{array}$ \\
\hline Heating set point, ${ }^{\circ} \mathrm{C}$ & 21 & 21 & 21 & 21 & 21 & 21 & 21 \\
\hline Cooling source & ASHP & & GSHP & Electricity & & - & GSHP \\
\hline Cooling system & $\begin{array}{l}\text { Central } \\
\text { AHU }\end{array}$ & - & $\begin{array}{l}\text { Ceiling } \\
\text { panel }\end{array}$ & Chiller & - & & $\begin{array}{l}\text { Ventilation } \\
\text { air }\end{array}$ \\
\hline Cooling set point, ${ }^{\circ} \mathrm{C}$ & 25 & - & 25 & 25 & - & - & 25 \\
\hline Ventilation system & $\begin{array}{c}\text { DCV } \\
\text { Two } \\
\text { steps }(40 \\
\text { or } 100 \%)\end{array}$ & $\begin{array}{c}\text { DCV } \\
\text { Two steps } \\
(25-40 \text { or } \\
100 \%)\end{array}$ & CAV & CAV & $\begin{array}{c}\text { DCV } \\
\text { Two } \\
\text { steps (50 } \\
\text { or } 100 \%)\end{array}$ & CAV & VAV \\
\hline $\begin{array}{l}\text { Airflow rate (nominal), } \\
1 /\left(\mathrm{s}^{2} \mathrm{~m}^{2}\right)\end{array}$ & 2.5 & 3.1 & 3.2 & 3.6 & 3.2 & 1.6 & 3.0 \\
\hline $\begin{array}{l}\text { Ventilation heat } \\
\text { recovery, \% }\end{array}$ & 67 & 75.6 & 73 & 77 & 71 & 75 & $67 \ldots 88$ \\
\hline $\mathrm{SFP}, \mathrm{kW} /\left(\mathrm{m}^{3} / \mathrm{s}\right)$ & 1.85 & 1.9 & 1.8 & 1.8 & 1.8 & 2.0 & $1.7 \ldots 2.3$ \\
\hline Onsite energy generation & - & - & - & PV panel & PV panel & - & PV panel \\
\hline
\end{tabular}

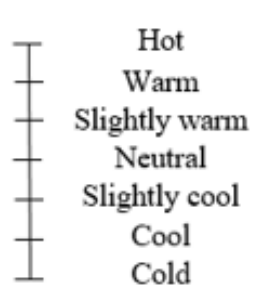

(a)

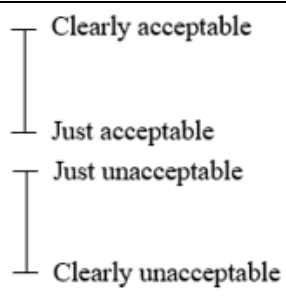

(b)

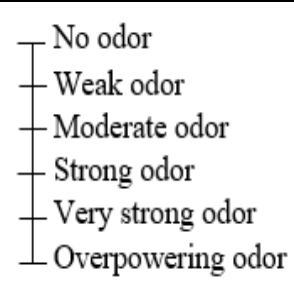

(c)

Fig. 3. Perceive level of a) Thermal sensation, b) IAQ, illuminance and acoustics level, c) Odor intensity.

\section{Results and analysis}

\subsection{Assessment of thermal environment}

The indoor temperature in buildings during measurement periods are reported in Table 4. Only occupied hours were considered, which categorized from I - IV according to the standard EN-15251. Category I represents the highest level of expectation and is recommended for spaces occupied by sensitive persons such as elderly and for measuring the supply air temperature, pressure difference along the envelope, supply and exhaust air flow rate. SWEMA $3000 \mathrm{md}$ measured the pressure difference in $\mathrm{Pa}$ with an accuracy of $\pm 0.3 \%$ and the supply air temperature with an accuracy of $\pm 0.5^{\circ} \mathrm{C}$. The measurements were taken as the average of 60 s duration in both measurement periods.

The questionaries' survey of EN-15251 was conducted during the measurement periods. The survey reported six questions about the overall indoor environmental condition. The perceived level of thermal comfort, IAQ, illuminance and acoustics level were scaled according to Figure 3. Odor intensity was scaled with six possible answers where 'No odor' and 'weak odor' were classified as acceptable levels. Staff members of the whole building were requested to participate in the questionnaire, and the total number of participants in both measurement periods are listed in Table 7. 
the room temperature more than the upper limit of category IV during the heating season.

The thermal environment during the heating season in all buildings except F4 was found to be in highest categories I and II (EN 15251) for a minimum of $95 \%$ of the occupied hours, which represents an excellent thermal comfort. Moreover, 13\% of occupied hours were classified as Category III in F4 building. However, 'Too warm' diagram showed that the temperatures were in between 24 and $25^{\circ} \mathrm{C}$ (warm side in Category III). On the other hand, a large percentage of occupied hours were in category IV during the cooling season. However, 'Too cold' diagram showed that the temperatures were in less than $22{ }^{\circ} \mathrm{C}$ (cold side in Category IV), which mainly occurred due to too low indoor temperature caused by cold outdoor temperature during the measurement period.

Table 4. Results of thermal comfort.

\begin{tabular}{ccccc}
\hline Category & 口IV & 口III & II & 口। \\
\hline Heating, ${ }^{\circ} \mathrm{C}$ & $\mathrm{T}<19$ or $\mathrm{T}>25$ & $22 \pm 3$ & $22 \pm 2$ & $22 \pm 1$ \\
\hline Cooling, ${ }^{\circ} \mathrm{C}$ & $\mathrm{T}<22$ or $\mathrm{T}>27$ & $24.5 \pm 2.5$ & $24.5 \pm 1.5$ & $24.5 \pm 1$ \\
\hline
\end{tabular}

F1

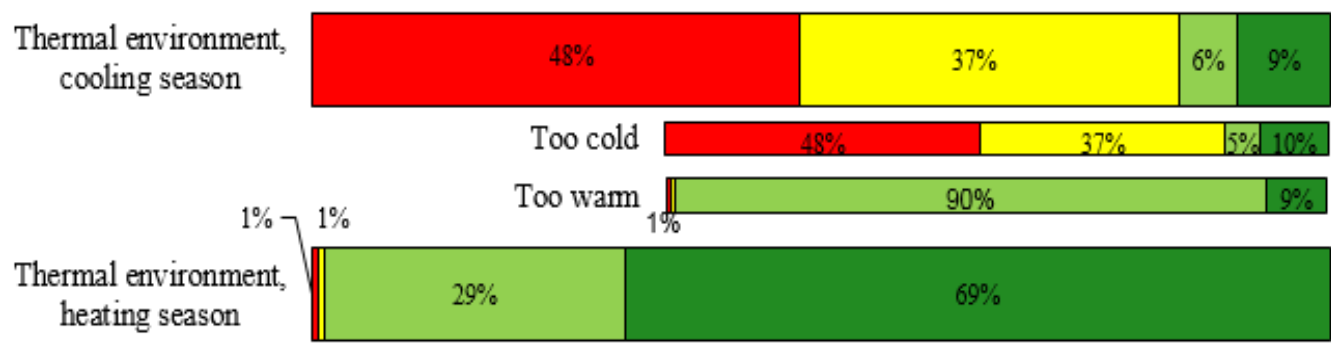

F2

Thermal environment,
cooling season
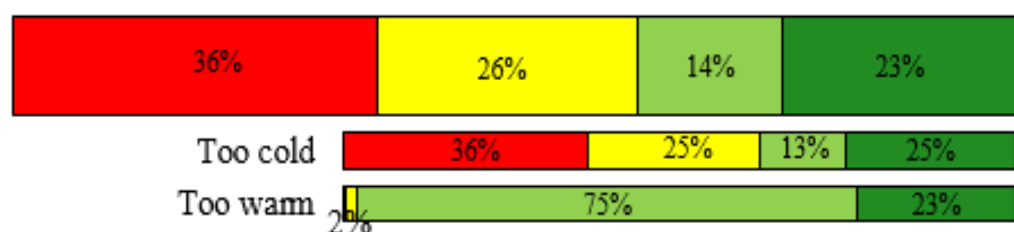

Too cold

Too warm

Thermal environment, heating season

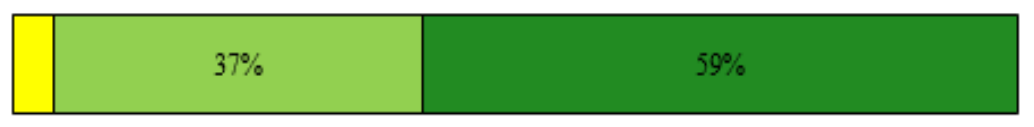

F3
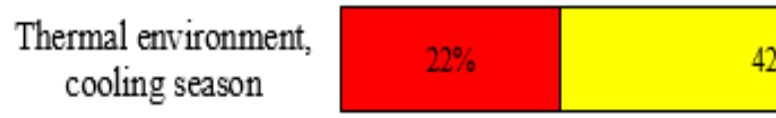

\section{$42 \%$}

$19 \%$

Too cold

Too warm

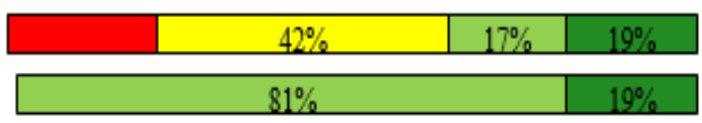

Thermal environment, heating season

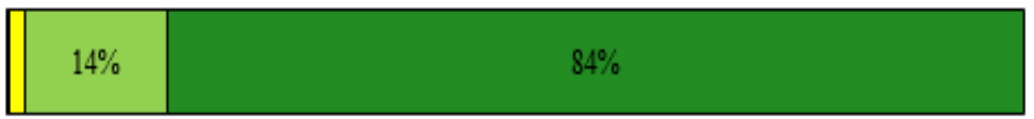

Thermal environment, cooling season

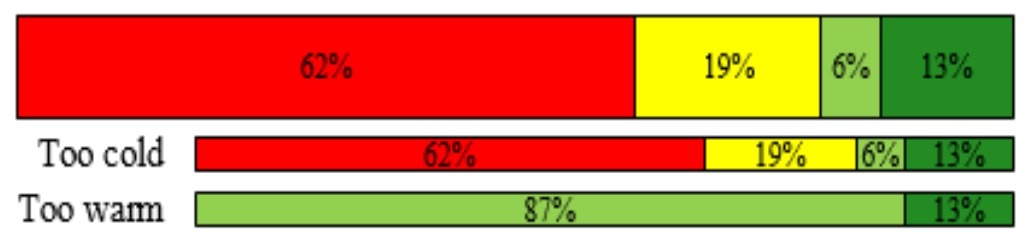

Thermal environment, heating season

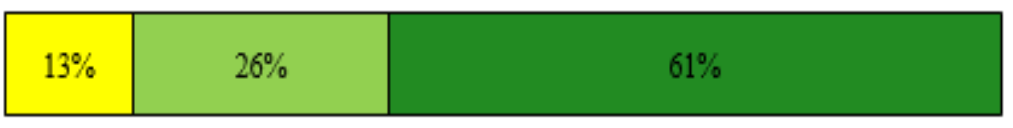


F5

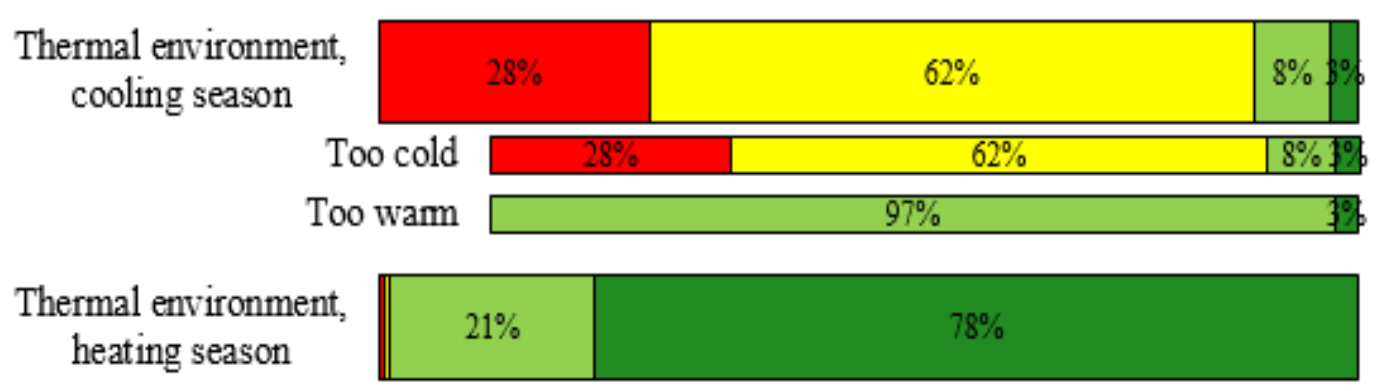

E1

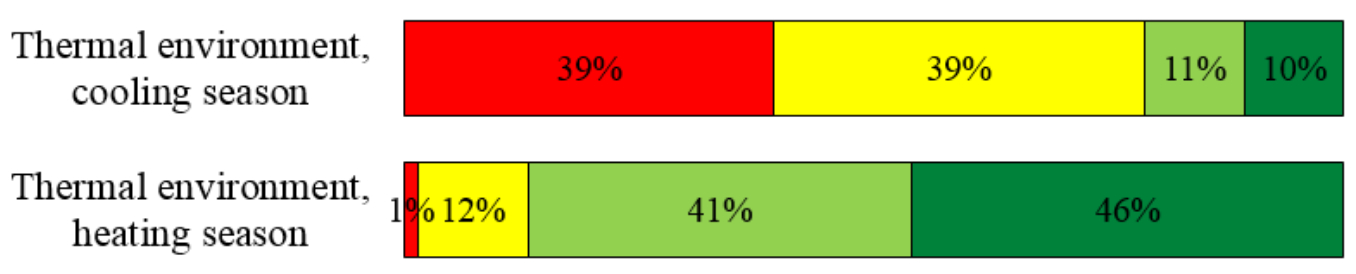

E2
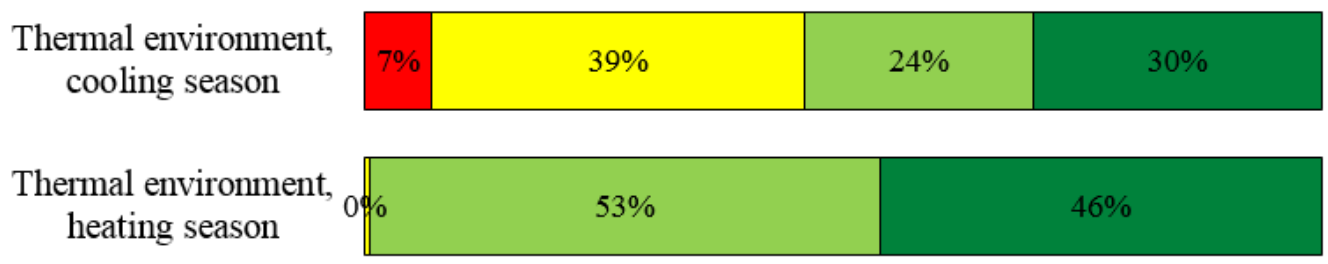

The average outdoor temperature during the measurement period in Kouvola and Espoo were 14.7 and $16.3{ }^{\circ} \mathrm{C}$, respectively. Measured indoor temperature and supply air temperature, as shown as duration curves in Figure 4. The supply air temperature was relatively uniform with CAV equipped ventilation system. In contrast, the DCV system controlled by temperature and $\mathrm{CO}_{2}$ sensor showed some fluctuation of supply temperature.

\subsection{Assessment of indoor air quality}

The indoor air quality in buildings during measurement periods are reported in Table 5. The measured $\mathrm{CO}_{2}$ concentration was classified into the Category of I - IV according to the standard EN-15251. The definition of each category has explained in the previous Section 3.1. The results found that all buildings achieved an excellent $\mathrm{CO}_{2}$ level that reflected the availability of dedicated and well-functioning ventilation systems in those buildings. Furthermore, for estimating the potential air infiltration, the pressure differences across the building envelopes were measured as shown in Table 6. The measurements were taken from different rooms, located in different parts of the building which gave a range of pressure differences. The results have shown that how well the ventilation systems were balanced.

\subsection{Questionaries' survey}

This study also conducted a questionaries' survey about the overall IEQ. The survey results during both seasons were available of two Finnish buildings out of five. A good correlation was found in between the questionaries' survey and the obtained footprints for all buildings except buildings F4 and F5.

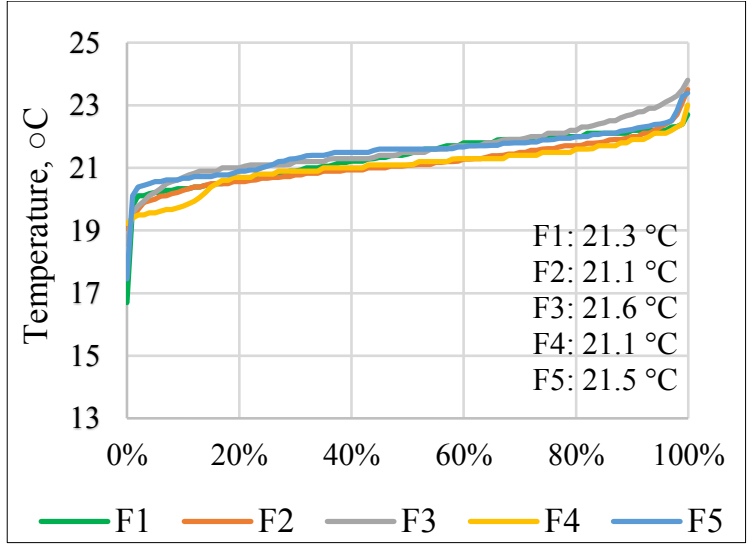

(a)

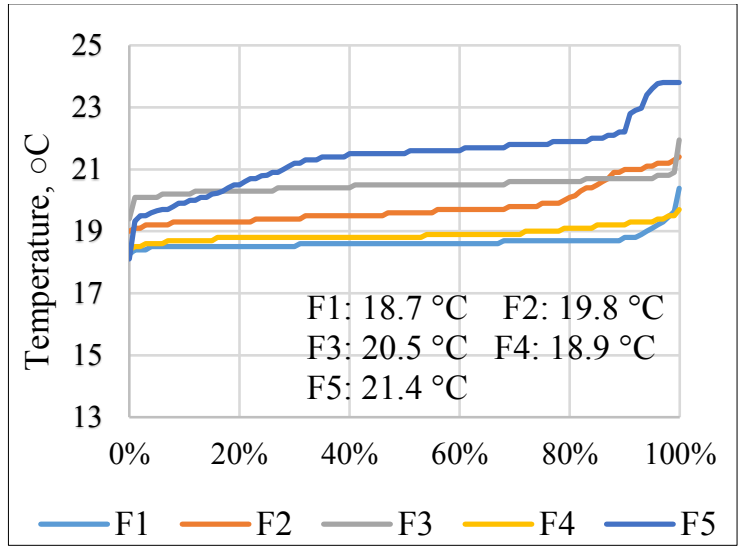

(b)

Fig. 4. Duration curve of a) Indoor temperature, and b) Supply air temperature in the heating season. 
Table 5. Results of indoor air quality.

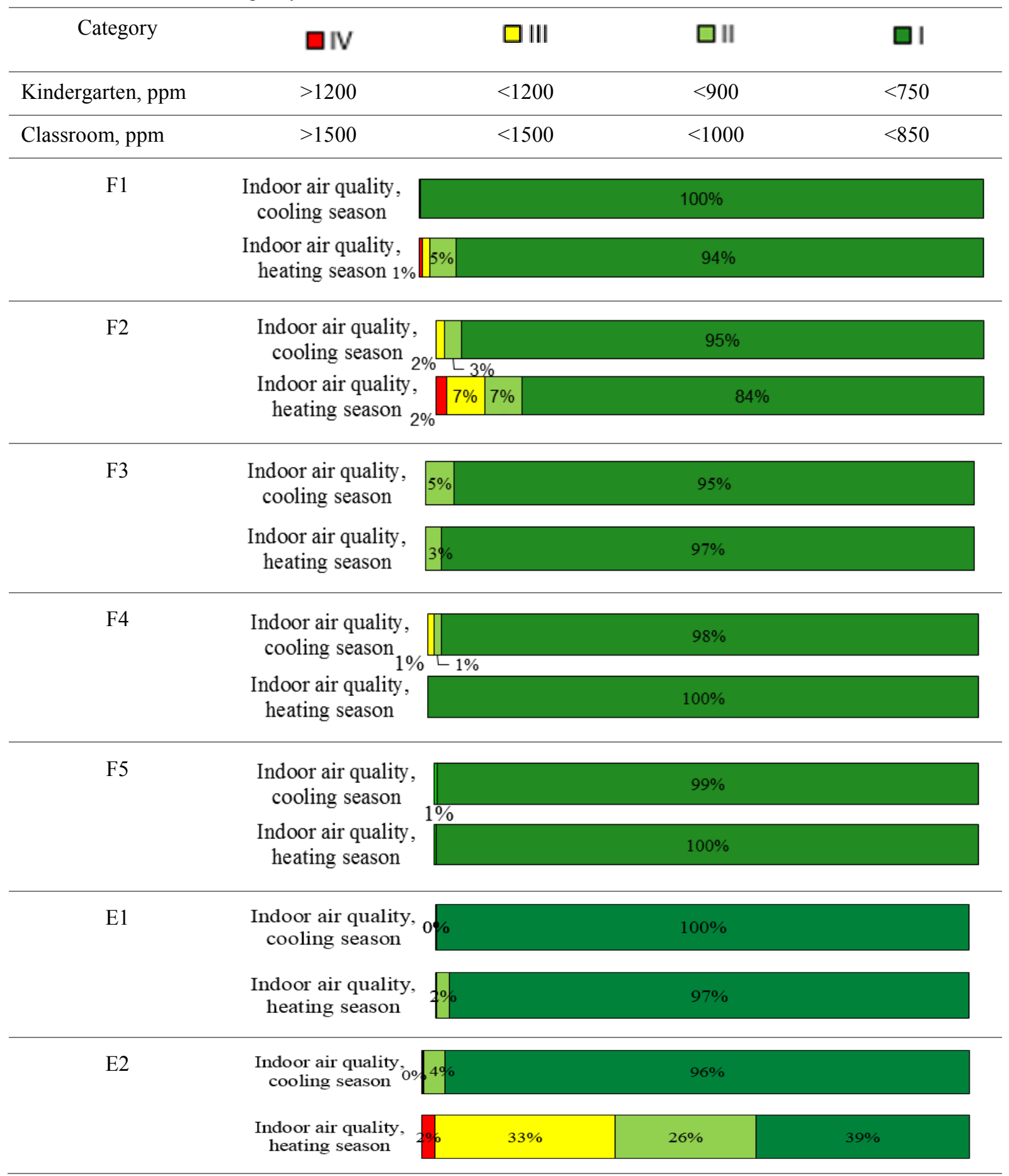

Table 6. The pressure difference across the envelope.

\begin{tabular}{lccccccc}
\hline Building code & F1 & F2 & F3 & F4 & F5 & E1 & E2 \\
\hline Heating season & -6.8 to 4.1 & -14.1 to 4.7 & 3.2 to 10.7 & 1.4 to 8.4 & -4.2 to -3.0 & - & - \\
\hline Cooling season & -1.0 to 2.6 & 0.7 to 12.1 & -11.2 to -4.7 & -1.9 to 3.3 & -0.8 to -4.8 & - & - \\
\hline
\end{tabular}

N.B. Negative values mean under-pressure indoors.

The results suggest the acceptance percentage over 80 can classify as a good one. In building F3, the satisfaction levels of $60-70 \%$ about the illumination and acoustic level that indicated the noise and glare problems in the building. Similarly, the occupant satisfaction levels of the thermal environment were $50 \%$ during the cooling season in building F4. These might be the reason of 'Too cold' situation (cold side in Category IV, Table 4) that also reflected the overall indoor environmental satisfaction results. The worst feedbacks about IAQ, odor, and acoustic were found in the F5 building, which indicated strong noise and odors related problems in the building. In Estonia, staff members who participated in the survey marked all indoor climate parameters at least acceptable. 


\subsection{Energy consumption}

Despite the presence of good indoor thermal condition and air quality in buildings F1-F4, the measured energy performance did not correspond to the calculated value. The measured energy use was by factor 2.1-2.6 higher compared to calculated value. The potential causes of remarkably higher energy consumption in F1 and F2 were the presence of a hot kitchen which did not take into account in energy calculation, absences of heat recovery unit in the kitchen, and constant operation of AHU with the aim to ventilate out the material emissions and to ensure high IAQ. Moreover, a full-time operation of the ventilation system and potential adjustments of technical systems were principal reasons for high energy use in F3 and F4 buildings (Construction year was 2017) during the first operational year. However, energy performance was achieved only in the F5 building. The detailed energy consumption data are shown in Table 8. In Estonia, the potential causes for significantly higher energy use were hot kitchen and swimming pool equipment, and outdoor lighting which were not taken into account in energy calculations. Also, the average indoor temperature in the heating season was $23{ }^{\circ} \mathrm{C}$ which is higher than $21^{\circ} \mathrm{C}$ that is used in energy calculations.

Table 7. Occupant satisfaction survey results.

\begin{tabular}{ccccccccc}
\hline & & $\begin{array}{c}\text { Number } \\
\text { of } \\
\text { participate }\end{array}$ & $\begin{array}{c}\text { Overall } \\
\text { indoor } \\
\text { environment }\end{array}$ & $\begin{array}{c}\text { Thermal } \\
\text { environment }\end{array}$ & $\begin{array}{c}\text { Indoor } \\
\text { air } \\
\text { quality }\end{array}$ & $\begin{array}{c}\text { Illuminance } \\
\text { level }\end{array}$ & $\begin{array}{c}\text { Acoustic } \\
\text { level }\end{array}$ & $\begin{array}{c}\text { Odor } \\
\text { intensity }\end{array}$ \\
\hline F1 & Winter & 16 & 94 & 100 & 88 & 100 & 100 & 81 \\
\hline F2 & Winter & 17 & 93 & 82 & 100 & 100 & 88 & 94 \\
\hline F3 & Winter & 10 & 82 & 100 & 100 & 70 & 60 & 80 \\
\hline & Summer & 10 & 86 & 100 & 100 & 60 & 80 & 90 \\
\hline F4 & Winter & 9 & 93 & 89 & 100 & 100 & 100 & 78 \\
\hline & Summer & 6 & 87 & 50 & 100 & 100 & 100 & 83 \\
\hline F5 & Winter & 20 & 67 & 80 & 65 & 85 & 40 & 65 \\
\hline E1 & Winter & 4 & 100 & 100 & 100 & 100 & 100 & 100 \\
\hline E2 & Winter & 5 & 100 & 100 & 100 & 100 & 100 & 100 \\
\hline
\end{tabular}

Table 8. Energy details and energy level according to EPC.

\begin{tabular}{|c|c|c|c|c|c|c|c|c|c|c|c|c|c|c|c|}
\hline \multirow{2}{*}{ 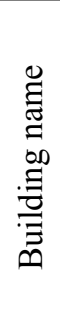 } & \multirow{2}{*}{ 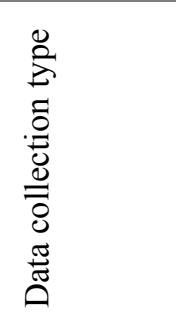 } & \multicolumn{4}{|c|}{$\begin{array}{c}\text { Heat, } \\
\mathrm{kWh} /\left(\mathrm{m}^{2} \mathrm{a}\right)\end{array}$} & \multicolumn{4}{|c|}{$\begin{array}{l}\text { Electricity, } \\
\mathrm{kWh} /\left(\mathrm{m}^{2} \mathrm{a}\right)\end{array}$} & \multicolumn{3}{|c|}{$\begin{array}{l}\text { On-site production, } \\
\mathrm{kWh} /\left(\mathrm{m}^{2} \mathrm{a}\right)\end{array}$} & \multirow{2}{*}{ 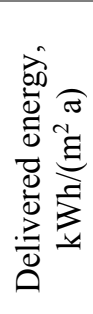 } & \multirow{2}{*}{ 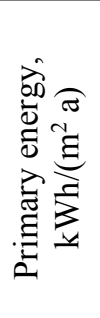 } & \multirow{2}{*}{$\frac{\bar{d}}{0}$} \\
\hline & & 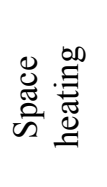 & 葛 & $\sum_{\overline{0}}^{3}$ & 蹗 & $\begin{array}{ll}\hat{\mathscr{E}} & \stackrel{n}{\Xi} \\
\stackrel{\Xi}{\Xi}\end{array}$ & 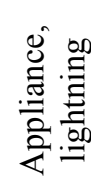 & ن & 吾 & 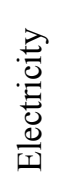 & $\stackrel{\bar{E}}{\stackrel{\mathscr{I}}{I}}$ & $\stackrel{\Xi ّ}{0}$ & & & \\
\hline \multirow[t]{2}{*}{ F1 } & Calculated & 39 & 29 & 14 & 83 & 18 & 33 & - & 51 & 0 & 0 & 0 & 133 & 169 & $\mathrm{C}$ \\
\hline & Measured & - & - & - & 220 & - & - & - & 106 & - & - & - & 327 & 401 & $\mathrm{G}$ \\
\hline \multirow[t]{2}{*}{ F2 } & Calculated & - & - & - & - & 39 & 32 & - & 71 & 0 & 60 & 60 & 71 & 121 & $\mathrm{~B}$ \\
\hline & Measured & - & - & - & - & - & - & - & 152 & - & - & - & 152 & 258 & $\mathrm{~F}$ \\
\hline \multirow[t]{2}{*}{ F3 } & Calculated & - & - & - & - & 36 & 25 & - & 61 & 0 & 42 & 42 & 61 & 104 & B \\
\hline & Measured & - & - & - & - & - & - & - & 155 & - & - & - & 155 & 264 & $\mathrm{~F}$ \\
\hline \multirow[t]{2}{*}{ F4 } & Calculated & 35 & 9 & 13 & 59 & 13 & 19 & 2 & 36 & 2 & 0 & 2 & 95 & 102 & B \\
\hline & Measured & - & - & - & 166 & - & - & - & 85 & - & - & - & 251 & 261 & $\mathrm{~F}$ \\
\hline \multirow[t]{2}{*}{ F5 } & Calculated & 14 & 6 & 16 & 38 & 7 & 18 & 0 & 29 & 2 & 0 & 2 & 67 & 75 & A \\
\hline & Measured & - & - & - & 33 & - & - & - & 35 & - & - & - & 68 & 83 & A \\
\hline \multirow[t]{2}{*}{ E1 } & Calculated & 76 & & 28 & 104 & 19 & 23 & - & 42 & - & - & - & 146 & 189 & $\mathrm{C}$ \\
\hline & Measured & 14 & & 7 & 153 & - & - & - & 49 & - & - & - & 202 & 251 & $\mathrm{E}$ \\
\hline \multirow[t]{2}{*}{ E2 } & Calculated & 5 & & 5 & 10 & 35 & 14 & 1 & 50 & 13 & - & 13 & 47 & 83 & A \\
\hline & Measured & - & & - & 1 & - & - & - & 124 & - & -- & - & 125 & 249 & $\mathrm{E}$ \\
\hline
\end{tabular}

\section{Conclusion}

This study assessed the indoor environmental quality of four daycare centers and three school buildings from Finland and Estonia. The conclusions are drawn based on the onsite measured data and questionaries' survey that were conducted during the heating and cooling seasons.
Also, comparison of energy use according to the energy performance certificate and onsite measured energy use in buildings had investigated in details. The following conclusions can be drawn:

- The highest category of indoor thermal condition (categories I and II) during the heating season was achieved in all buildings; 
- A high percentage of occupied hours in buildings F1 to F5 were in Category IV during the cooling season. It occurred due to 'Too cold' room temperature that below than $22^{\circ} \mathrm{C}$, which was caused by extremely cold outdoor temperatures at the measurement period;

- All buildings except E2 achieved category I and II $\mathrm{CO}_{2}$ levels, revealing that buildings were equipped with well-functioning ventilation systems;

- Occupant satisfaction about the overall indoor environment was found higher than $80 \%$ in 6 out of 7 buildings, which showed a reasonable correlation between measured and questionnaire results;

- Worst feedbacks were found from Building F5, indicating the presence of noise and odors related problems;

- The measured energy use in 5 out of 7 buildings was by factor 2.1-3.0 higher compared to the calculated value according to EPC. Presence of hot kitchens, a swimming pool, absence of heat recovery unit in kitchens, and continuous operation of the ventilation system were the potential causes of higher energy consumption. Additionally, indoor temperatures higher by $2 \mathrm{~K}$ compared to heating set-point were figured out as the possible reasons for high energy use in Estonian buildings.

\section{Acknowledgment}

This work was supported by European Union's Horizon 2020 research and innovation programme, NERO project No 754177.

\section{References}

[1] L. D. Pereira, D. Raimondo, S.P. Corgnati and M. Gameiro da Silva, "Energy consumption in schools - A review paper," Renewable and Sustainable Energy Reviews, vol. 40, pp. 911-922 (2014).

[2] "Alliance to save energy" Date of access October/2018, www.ase.org.

[3] D.F. Motta Cabrera and H. Zareipour, "Data association mining for identifying lighting energy waste patterns in educational institutes," Energy and Buildings, vol. 62, pp. 210-216 (2013).
[4] K. Ahmed, E. Sistonen, R. Simson, J. Kurnitski, J. Kesti and P. Lautso, "Radiant panel and air heating performance in large industrial building," Building Simulation, vol. 11, no. 2, pp. 293-303 (2018).

[5] K. Ahmed, J. Kurnitski and P. Sormunen, "Demand controlled ventilation indoor climate and energy performance in a high performance building with air flow rate controlled chilled beams," Energy and Buildings, vol. 109, pp. 115-126 (2015).

[6] J. Kurnitski, K. Ahmed, R. Simson and E. Sistonen, "Temperature distribution and ventilation in large industrial halls," Proceedings of the 9th Windsor conference: making comfort relevant, Cumberland Lodge, UK., pp. 340-348 (2016).

[7] Y. Allab, M. Pellegrino, X. Guo, E. Nefzaoui and A. Kindinis, "Energy and comfort assessment in educational building: Case study in a French university campus," Energy and Buildings, vol. 143, pp. 202219 (2017).

[8] S.A. Ghita and T. Catalina, "Energy efficiency versus indoor environmental quality in different Romanian countryside schools," Energy and Buildings, vol. 92, pp. 140-154 (2015).

[9] E.G. Dascalaki and V.G. Sermpetzoglou, "Energy performance and indoor environmental quality in Hellenic schools," Energy and Buildings, vol. 43, no. 2, pp. 718-727 (2011).

[10] W. Vornanen C., K. Järvi, S. Toomla, K. Ahmed, A. Andersson M., R. Mikkola, T. Marik, L. Kredics, H. Salonen and J. Kurnitski, "Ventilation Positive Pressure Intervention Effect on Indoor Air Quality in a School Building with Moisture Problems," Int. J. Environ. Res. Public Health, vol. 15, no. 2, pp. 230-252 (2018).

[11] C. Vornanen-Winqvist, S. Toomla, K. Ahmed, J. Kurnitski, R. Mikkola and H. Salonen, "The effect of positive pressure on indoor air quality in a deeply renovated school building - a case study," Energy Procedia, vol. 132, pp. 165-170 (2017).

[12] P. de Wilde, "The gap between predicted and measured energy performance of buildings: A framework for investigation," Automation in Construction, vol. 41, pp. 40-49 (2014).

[13] L. La Fleur, B. Moshfegh and P. Rohdin, "Measured and predicted energy use and indoor climate before and after a major renovation of an apartment building in Sweden," Energy and Buildings, vol. 146, pp. 98110 (2017).

[14] U. Dar I., L. Georges, I. Sartori and V. Novakovi, "Influence of occupant's behavior on heating needs and energy system performance: A case of well-insulated detached houses in cold climates," Building Simulation, vol. 8, no. 5, pp. 499-513 (2015).

[15] Z. Wang, Z. Zhao, B. Lin, Y. Zhu and Q. Ouyang, "Residential heating energy consumption modeling through a bottom-up approach for China's Hot Summer-Cold Winter climatic region," Energy and Buildings, vol. 109, pp. 65-74 (2015). 